\title{
СИНТЕЗ И IN SILICО-ИССЛЕДОВАНИЯ \\ НОВЫХ АЗОЛИЛ-ЗАМЕЩЕННЫХ ПРОИЗВОДНЫХ ЦИКЛИЧЕСКИХ НИТРОНОВ
}

\author{
А.А. Акулов, М.В. Вараксин ${ }^{1,2}$, И.И. Буторин, , В.Н. Чарушин ${ }^{1,2}$, О.Н. Чупахин ${ }^{1,2}$ \\ ${ }^{1}$ Кафедра органической и биомолекулярной химии, УрФУ им. первого Президента России \\ Б.Н.Ельцина, 620002, Россия, Екатеринбург, ул. Мира, 19. \\ ${ }^{2}$ ИОС им. И.Я.Постовского УрО РАН, 620990, Россия, Екатеринбург, ул. С. Ковалевской, 22.
}

DOI: 10.19163/MedChemRussia2021-2021-236

E-mail:a.a.akulov@urfu.ru

Циклические нитроны представляют собой соединения, вызывающие живой интерес для медицинской химии как с точки зрения своей практической значимости, так и с позиции синтетической многогранности. В частности, в серии исследований на примере модельных альдонитронов, 2H-имидазол-1-оксидов, была продемонстрирована возможность прямой модификации таких соединений различными функциональными фрагментами с использованием стратегии прямой активации азометиновой С-Н-связи [1].

Было показано, что 2Н-имидазол-1-оксиды 1 способны вступать в реакции кросс-дегидрогенативного сочетания с рядом $\mathrm{NH}$-содержащих азолов 2 в присутствии реагента Selectfluor ${ }^{\circledR}$ [2]. Более того, существенного увеличения выходов продуктов таких сочетаний (3) удалось достичь при использовании видимого света в качестве источника энергии.

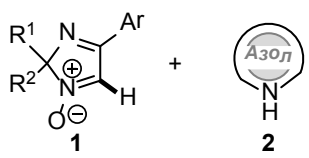

2
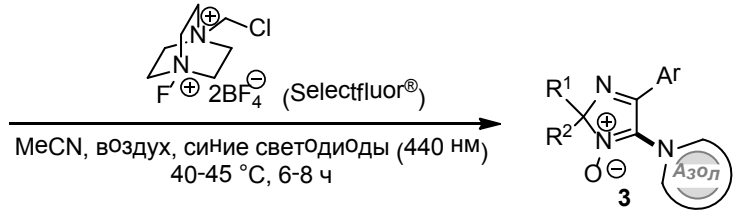

25 примеров, выходы до $94 \%$

Для ряда структур, отвечающих общей формуле 3, были проведены in silico-исследования в части определения аффинности к некоторым мишеням, ассоциированным с прогрессированием болезни Альцгеймера $\left(5 \mathrm{HT}_{2 \mathrm{~A}}, 5 \mathrm{HT}_{6}, \mathrm{~A}_{2 \mathrm{~A}}\right.$ рецепторам, а также бета-секретазе BACE1). В результате молекулярного докинга для каждой из мишеней определены лиганды-лидеры, чьи свободные энергии связывания оказались ниже показателей, установленных для стандартных нативных лигандов, использованных для сравнения.

Исследование проводилось при финансовой поддержке Российского научного фонда в рамках научного проекта 20-43-01004.

\section{Литература}

[1] A.A. Akulov, M.V. Varaksin, P. Mampuys, V.N. Charushin, O.N. Chupakhin, and B.U.W. Maes, Org. Biomol. Chem. 2021, 19, 297-312.

[2] A.A. Akulov, M.V.Varaksin, A.N. Tsmokalyuk, V.N. Charushin, and O.N. Chupakhin, Green Chem. 2021, 23, 2049-2057. 